\title{
Association of Socio-Economic Characteristics with the Training Needs of Cherry Growers-A Study in Baramulla District of Kashmir Valley
}

\author{
Dawood Yousuf ${ }^{1}$, M. A. Dar ${ }^{1}$, Noor Ul Islam Wani ${ }^{2^{*}}$, Nakeeb Raja ${ }^{1}$, \\ Junaid Rishu ${ }^{1}$ and Aamir Hamid Shah ${ }^{1}$ \\ ${ }^{1}$ Division of Agri. Extension \& Communication, FoA, SKUAST-K Wadura, India \\ ${ }^{2}$ Department of Agriculture, $J \& K$, India \\ *Corresponding author
}

\author{
A B S T R A C T
}

\begin{tabular}{l} 
Ke y w o r d s \\
Cherry, \\
Respondents, \\
KNOWLEDGE \\
level, Education, \\
Experience, \\
Training needs \\
\hline Article Info \\
\hline $\begin{array}{l}\text { Accepted: } \\
18 \text { April } 2020 \\
\text { Available Online: } \\
\text { 10 May } 2020\end{array}$ \\
\hline
\end{tabular}

The study was conducted in horticulture zone Tangmarg of district Baramulla of jammu and Kashmir. Horticulture Zone Tangmarg comprises of 65 villages out of which 35 villages were under cherry cultivation. From 35 villages 06 villages were selected purposively on the basis of maximum area under cherry cultivation. From the selected 06 villages, 120 cherry growers were selected through proportionate allocation method. Invariable farmer characteristics were undertaken to assess the training needs of farmers. The study revealed that majority of the respondents $(54.14 \%)$ were of young age group (upto 35 years), majority $(57.17 \%)$ of the respondents had received education upto middle school. The size of land holding of small number of the respondents $(6.66 \%)$ was medium (2.01-5 ha) and majority of the respondents were having medium family size of (5-10) members. So far as annual income is concerned small number of respondents (15\%) were having high annual income (above Rs 260000). Majority of the respondents (67.50) have farming experience of below 11 years. Majority (43.33\%) of the respondents were having low source of information and (47.50\%) of the respondents were having medium economic motivation. So far as risk proneness and scientific orientation is concerned majority of the respondents $(39.17 \%)$ were having low risk proneness and majority $(56.66 \%)$ was having low scientific orientation. It was observed that Education, land holding, annual income, Farming experience, Scientific orientation, Risk proneness and economic motivation were positively correlated with the training needs whereas, Age, Experience and Source of information were negatively correlated and highly significant. It was concluded that need based cost effective training programme and strategies need to be tailored, so that human resource be put to effective use for achieving sustainable cherry production.

\section{Introduction}

Cherry fruit is a fleshy non-climacteric stone fruit which belongs to family Rosaceae and genus Prunus. It is the first stone fruit of summer to blossom and produce fruits. Cherry is one of the most widely appreciated fruit for its taste, colour, sweetness and myriad of nutrients. It is mostly consumed as fresh fruit, dried, pickled and processed in juice and jam. There are many species of cherry namely sweet cherry, tart cherry, black cherry etc. grown in the world. Sweet cherry grown in temperate climate is commercially cultivated in more than 40 countries worldwide mainly between $33^{\circ} \mathrm{N}$ and $55^{\circ} \mathrm{S}$ 
latitude where temperature and other factors are favorable for its growth. Sweet cherry is considered native to the Caspian Sea between some areas of Europe and many parts of Asia (Chadha, 2003).

The major cherry producing countries in the world are Turkey, USA, Iran, Italy, Spain, Russia, Chile, France, and Germany. The total area under cherry cultivation in world was $(151,004 \mathrm{Ha})$ and production $(2,185,881 \mathrm{Mt})$ (Anonymous 2015). United States is the largest exporter of cherry in the world and accounts 29 per cent of total share of world export followed by Chile (16\%). Michigan is the top cherry producing state of US and is called as cherry capital of world (Anonymous, 2012).

The total area under cherry cultivation in Jammu and Kashmir state was (2816 hac) with a production of (10244 MTs) and Baramulla District has an area of (212 ha) with a production of 1285.62 MTs (Anonymous, 2017).

Consumers demand for sweet cherry has increased due to its sweet taste, attractive colour and high amount of antioxidants. However, the fruit being highly perishable with a limited shelf life of 7-10 days and in some cases the produce fails to reach the consumer at optimal quality. Spring frost, fruit drop, loss of colour, firmness, flavour, and desiccation are the main problems faced by cherry growers.

This may be due to low adoption of recommended package of practices by the cherry growers, growing of local/early blooming varieties, imbalanced use of fertilizer dose, non-adoption of recommended spray schedule, improper picking, handling and packaging practices. For achieving the target in any enterprise, the target group needs to be highly trained and skillful.
Training is a process of new skills, attitude and knowledge in the context of preparing/improving one's productivity in an enterprise. Effective training requires a clear picture how the trainees or farmers will need to use the skills after training in place of local practices. Training is one of the commonly used methods that impart knowledge and skill to the trainees. Training is viewed as an investment in human resources. Training is an essential source to induce motivation, create confidences and inculcate efficiency in an individual. Training only can bridge the enormous gap between remarkable yield achieved by the scientists and yield obtained by the farmers (Hanumanlal and Pawar, 1995). Training of the farmers is carried out so as to be fitted, qualified and proficient. The purpose is to impact knowledge and skills to the farmers so that, they can perform some desirable tasks (Halim and Ali, 1988). In order to make any training meaningful and effective, it is imperative on the part of the training organizers to identify the training needs of the farmers based on which suitable training module can be developed so that the appropriate training is given to the right people in the right form at the right time so that higher degree of productivity and profitability can be achieved (Prajapati and Patel, 2006). Keeping in view the importance of the cherry crop and the training required for the cultivation of the same on scientific lines, the present study "Association of SocioEconomic Characteristics with the Training Needs of Cherry Growers- A Study in Baramulla District of Kashmir Valley" was carried out in Baramulla district of Kashmir valley in 2017-18.

\section{Personal and socio-economic profile of the cherry growers}

The characteristics of Cherry growers in terms of personal and socio-economic aspects are presented as - 


\section{Materials and Methods}

\section{Sampling techniques}

The sample of the present study was drawn through following three stages of sampling method to obtain the required information. These were:

i) Selection of Horticulture zone

ii) Selection of villages

iii) Selection of respondents.

\section{Selection of horticulture zone}

District Baramulla comprises of 19 horticulture Zones, among them only one Horticulture Zone, i.e Horticulture Zone Tangmarg was selected purposively for the study having maximum area and production under cherry fruit in the district.

\section{Selection of villages}

The list of villages under cherry fruit cultivation was obtained from the office of Horticulture Zone Tangmarg. It comprises of 65 villages, out of which 35 villages are under cherry cultivation.Among these villages, only 06 villages were selected purposively on the basis of having maximum area under cherry fruit cultivation namely Hajibal,Mulbangil, Budipora, Warpora, Katipora, Budipora and Watalpora.

\section{Selection of respondents}

The list of cherry growers of the selected villages was prepared in consultation with village heads and field extension functionaries of the horticulture department .For the study purpose, the cherry growers were selected through proportionate random sampling method from each selected village. Thus a total of 120 cherry growers were selected for the study.
List of selected villages and number of selected respondents

\begin{tabular}{|l|l|c|c|}
\hline S.No & $\begin{array}{l}\text { Name of the } \\
\text { village }\end{array}$ & $\begin{array}{c}\text { Total } \\
\text { No. of } \\
\text { cherry } \\
\text { growers }\end{array}$ & $\begin{array}{c}\text { No of } \\
\text { Selected } \\
\text { respondents }\end{array}$ \\
\hline $\mathbf{0 1}$ & Warpora & 105 & 22 \\
\hline $\mathbf{0 2}$ & Budipora & 75 & 16 \\
\hline $\mathbf{0 3}$ & Watalpora & 80 & 17 \\
\hline $\mathbf{0 4}$ & Katipora & 135 & 28 \\
\hline $\mathbf{0 5}$ & Mulbangil & 90 & 19 \\
\hline $\mathbf{0 6}$ & Hajibal & 85 & 18 \\
\hline Total & & 570 & 120 \\
\hline
\end{tabular}

By proportionate allocation method

\section{Designing of interview schedule}

An interview schedule based on objectives, variables and available literature on the topic was prepared. The cultivation practices developed by the Agriculture university (SKUAST - K) were incorporated in the schedule so as to know on which practice the farmer needs to have training. The interview schedule was prepared in English language.while preparing the interview schedule, due care was taken to avoid questions with dual meaning and contradicting statements. The language used for the questions was simple for easy understanding of the respondents.

\section{Pre-testing of interview schedule}

Before finalization of the interview schedule, it was pre-tested to detect the mistakes and short falls and to achieve clarity and practicability of the schedule by selecting ten respondents who were not included in the sample. The prepared interview schedule was examined and necessary modifications were made in light of ambiguities, difficulties and experience in data collection. 


\section{Procedure of data collection}

The author personally interviewed the respondents included in the sample. The help of village leaders and horticulture extension functionaries was sought for establishing the rapport with the cherry growers. The imperative end objectives of the study were clearly explained to the cherry growers. The respondents were assured, that the information furnished by them would be kept confidential and would be used for the research study only. The interview was conducted in a friendly and informal manner.

\section{Compilation of data}

The qualitative data was quantified by using various statistical tools and working out different scores in order to find out the nature of association between dependent and independent variables.

\section{Age}

The data in Table 1 reveals, that 54.16 per cent of cherry growers were of young age (up to 36 years), followed by middle age (31.66\%) and 14.16 per cent were of old age (above 63 years) .

The results of the present study shows that higher percentage of Cherry growers $(54.16 \%)$ belonged to young age group (upto 36 years).It might be because of the reason that farmers of young age are enthusiastic, having more responsibility, more physical vigour and more efficient than the middle and older ones. The results of Patel (2007) and Asane (2003) are in line with the present findings.

\section{Education}

The data in Table 1 reveals, that out of the total cherry growers, 57.17 per cent were educated up to middle standard, 26.67 per cent were educated up to higher secondary level $(10+2)$ and only 19.16 per cent had education above higher secondary level.

Thus, it can be concluded that majority $(57.17 \%)$ of cherry growers had received education upto middle school. The possible reason for this could be that large distance of study centers from the villages, illiteracy of the parents, might have come in the way of getting their children the better education. The above findings get support from the studies conducted by Prajapati (2006).Since, majority of the respondents were illiterate, the training programmes to be imparted should be formulated as per the literacy level of the respondents.

\section{Family size}

The data in Table 1 reveals, that 54.17 per cent of cherry growers had medium family size, followed by large family size (26.66\%) and 19.17 per cent belonged to small family size.

Thus, it can be concluded that higher percentage $(54.17 \%)$ of cherry growers belonged to medium family size and small percentage were having small family size upto 4 members. The above findings are in line with the study conducted by Shah (2017) and Ali (2013).

\section{Land holding}

The data in Table 1shows, that out of total respondents, 73.33 per cent had marginal land holding (upto $1 \mathrm{hec}$ ), followed by 20 per cent having small land holding (1.01-2 hec) and only 6.66 per cent had medium land holding (2.01-5hec).

Thus, it can be concluded that higher percentage of cherry growers had marginal 
land holding and small percentage had medium land holding (2.01-5hec). The reason might be that most of the cherry growers in kashmir valley belong to marginal category. To enhance the productivity per unit area is present days demand.

Majority of the cherry growers had marginal land holding, so production can only be raised by improving productivity and that needs proper training to adopt the new innovations. These findings are in line with the findings of Laxminarayana et al., (2000).

\section{Annual income}

Cherry growers were categorized into Income Group I, Income Group II and Income Group III on the basis of annual income. The data in Table 1 reveals, that higher percentage $(65.00 \%)$ of cherry growers belong to income group I having annual income of Rs 100000 , followed by income group II (20\%) having annual income of Rs 100000-Rs 260000 and minimum percentage $(15 \%)$ belonged to income group III having annual income above Rs 260000.

Thus, it can be concluded that higher percentage $(65 \%)$ of cherry growers were having low annual income. The findings get support with the work of Singh et al., (2012). The trainings to be imparted should be conducted at the farmers field rather than at university or KVK campus which is expensive and time consuming for the fruit growers.

\section{Farming experience}

The data in Table 1 reveals, that 67.50 per cent of cherry growers had farming experience of upto 11 years, followed by 17.50 per cent having farming experience ( 12-27 years) and fifteen per cent of cherry growers had farming experience (above 27 years).
Thus, it can be concluded, that majority $(67.50 \%)$ of cherry growers had low level of farming experience. The possible reason could be that most of the cherry growers are of young age group. The above findings are in line with the study conducted by Ghodeswar (2006) and Patalia (1991).

\section{Source of information}

The data in Table 1 reveals, that 43.33 per cent of cherry growers had low level of source of information, followed by 36.67 per cent of cherry growers having medium level of source of information and only twenty per cent had high level of source of information.

Thus it can be concluded that near about fifty per cent of the cherry growers had low exposure to information. This might be due to low level of education of the cherry growers with the result, farmers may not be able to read literature, farm magazines and attend the workshops and conferences.

Other reasons could be, that the training programmes being conducted by concerned horticulture departments either less frequently or with less popularity. The lack of initiation or interest on the part of respondents could also be the reason for the present findings. The trend was in line with the findings of Chowdhary (2006), Kadam et al., (2014) and Raghuwanshi (2014).

\section{Economic motivation}

Data in Table1 reveals, that a majority $(47.50 \%)$ of the cherry growers had medium level of economic motivation, followed by 38.33 per cent of the cherry growers having low level of economic motivation and a low percentage $(14.17 \%)$ of the cherry growers had high level of economic motivation. Thus, it can be concluded that majority $(47.50 \%)$ of the cherry growers belonged to medium level 
of economic motivation. This indicated, that the cherry growers are becoming more aware and are trying to maximize their income. The findings are supported by Dolliand Sundaraswamy (1994) and Hipperkar (2015).

\section{Risk proneness}

The data in Table 1 reveals, that a majority $(39.17 \%)$ of cherry growers had low level of risk proneness, followed by 35 per cent of the cherry growers having medium risk proneness and 25.83 percent of the cherry growers had high level of risk proneness.

Thus, it can be concluded that majority of the cherry growers had low level of risk proneness.

It indicates that cherry growers were not prone to take the adequate risk and face the challenges to maximize their returns. The findings are supported by Khandare (2003) and Waghmare (2010).

\section{Scientific orientation}

The data in Table 1 indicated, that a majority of the cherry growers $(56.67 \%)$ possess low level of scientific orientation. whereas, 29.17 per cent had medium level of scientific orientation and 14.16 percent of the cherry growers had high level of scientific orientation.

Thus, it can be concluded that majority of the cherry growers having low level of scientific orientation effects the training needs, as most of the cherry growers were illiterate and were doing traditional farming.

So, they are in more need of trainings as compared to the educated famers with good enough scientific orientation. The findings are in conformity with the findings of Lokhande (2007).
Association between personal and socioeconomic characteristics of cherry growers with training needs

From Table 2, it was observed that 43.08 per cent and 40.0 per cent cherry growers belonged to medium and high training needs category respectively. Whereas, In case of young age group, 16.92 per cent respondents belonged to low training needs category . Similarly, in middle age group, 63.16 per cent had high training needs, 21.05 per cent had low training needs, followed by 15.79 per cent having medium training needs. In case of old age group, 35.30, 35.29 and 29.41 per cent respectively had low, high and medium training needs. The chi ${ }^{2}$ value 11.041 was found to be significant at 5 per cent level of probability. Thus null hypothesis was rejected thus it can be concluded that age had an effect on the training needs of cherry growers.

From Table 3 it was observed, that in the category of low education level, 47.70, 38.46 and 13.84 per cent respondents had high, medium and low training needs respectively. Similarly, in case of cherry growers having medium education level, 62.50 per cent and 21.87 per cent had high and medium training needs followed by 15.62 per cent respondents having low training needs. As regards to cherry growers having high education level, 47.83 per cent ,30.43 per cent and 21.74 per cent respondents had low, medium and high training needs.

The chi $^{2}$ value 16.63 was found to be significant at 5 per cent level of probability. Hence, the null hypothesis was rejected and it can be concluded that education had considerable effect on the training needs of cherry growers. From Table 4, it was observed that in the category of small family size, 43.48 per cent and 30.44 per cent respondents had high and medium training needs and 26.08 per cent respondents had low 
training needs. Similarly, in case of medium size family , 53.85 per cent had high training needs followed by 29.23 per cent and 16.92 having medium and low training needs respectively and in case of large family size,40.62,34.38 and 25.00, per cent respectively had medium, high and low training needs. The $\mathrm{chi}^{2}$ value 3.746 was found to be non-significant at 5 per cent level of probability. Thus, null hypothesis was accepted and it can be concluded that family size has no association with the training needs of cherry growers.

From Table 5, it was observed that among the cherry growers having marginal land holding, 48.86 per cent had high training needs, 34.09 per cent and 17.04 per cent of cherry growers had medium and low training needs respectively. Similarly, in the category of small land holding cherry growers 37.50 per cent had low training needs, 29.17 per cent and 33.33 per cent had high and medium training needs respectively. In case of cherry growers having medium land holding, 25 per cent had medium training needs, 12.50 per cent and 4.16 per cent had low and high training needs respectively. The $\mathrm{chi}^{2}$ value 5.79 was found to be non-significant at 5 per cent level of probability. Thus, the null hypothesis was accepted and it can be concluded that land holding had no association with the training needs of cherry growers.

From Table 6 it was found, that in income group category I of cherry growers, 51.28 per cent had high training needs ,34.62 per cent and 14.10 per cent had medium and low training needs respectively. In case of cherry growers falling in income group II, 41.67 per cent had high training needs, 33.33 per cent and 25 per cent had low and medium training needs respectively. Similarly, in case of income group category III, 33.33 per cent each had low, medium and high training needs respectively. The $\mathrm{chi}^{2}$ value 6.543 was found to be non- significant at 5 per cent level of probability. Thus, the null hypothesis was accepted and the variable annual income had no association with the training needs of cherry growers.

From Table 7, it is clear from the data, that 54.32 per cent having low farming experience had high training needs, while 33.33 and 12.34 per cent respectively had medium and low training needs respectively. In case of cherry growers having medium farming experience, 42.84 per cent had low training needs, followed by 28.58 per cent having medium and 28.58 per cent having high training needs. Whereas, cherry growers having high farming experience, 33.33 per cent each had low, medium and high training needs respectively. The chi ${ }^{2}$ value 12.33 was found to be significant at 5 per cent level of probability. Thus, the null hypothesis was rejected and it can be concluded that farming experience has association with training needs of the cherry growers.

From Table 8 it was found, that in the case of cherry growers with low source of information, 44.23 per cent had high training needs, 42.31 per cent and 13.46 per cent had medium and low training needs respectively. Whereas, cherry growers having medium level of source of information, 54.55 per cent had high training needs, 27.27 per cent and 18.18 per cent had medium and low training needs respectively. Similarly, in case of cherry growers having high source of information , 41.67 per cent had low training needs followed by 37.50 per cent and 20.83 per cent had high and medium training needs respectively. The chi $^{2}$ value 10.50 was found to be significant at 5 per cent level of probability. Thus, the null hypothesis was rejected and the variable source of information was associated with training needs of cherry growers. 
Table.1 Distribution of cherry growers according to their personal and socio-economic characteristics $(\mathrm{N}=120)$

\begin{tabular}{|c|c|c|c|c|c|c|}
\hline S.NO & Characteristics & Category & $\mathbf{F}$ & $\%$ age & Mean & S.D \\
\hline \multirow{3}{*}{01} & \multirow{3}{*}{ Age } & Young ( < 36 Years) & 65 & 54.17 & \multirow[b]{3}{*}{49.29} & \multirow[b]{3}{*}{13.60} \\
\hline & & Middle (37-63Years) & 38 & 31.67 & & \\
\hline & & Old $(>63$ Years $)$ & 17 & 14.16 & & \\
\hline \multirow{3}{*}{02} & \multirow{3}{*}{ Education } & Up to middle school & 65 & 54.17 & \multirow[t]{3}{*}{-} & \multirow[t]{3}{*}{-} \\
\hline & & Middle to $10+2$ & 32 & 26.67 & & \\
\hline & & Above $10+2$ & 23 & 19.16 & & \\
\hline \multirow{3}{*}{03} & \multirow{3}{*}{ Family size } & Small (up to 4 members) & 23 & 19.17 & \multirow{3}{*}{7.05} & \multirow{3}{*}{2.69} \\
\hline & & $\begin{array}{l}\text { Medium } \\
\text { Members })\end{array}$ & 65 & 54.17 & & \\
\hline & & Large( $>10$ Members $)$ & 32 & 26.66 & & \\
\hline \multirow{3}{*}{04} & \multirow{3}{*}{ Land Holding } & Marginal (up to 1hec) & 88 & 73.33 & \multirow[t]{3}{*}{-} & \multirow[t]{3}{*}{-} \\
\hline & & Small (1.o1-2 hec) & 24 & 20.00 & & \\
\hline & & Medium (2.o1-5 hec) & 8 & 6.66 & & \\
\hline \multirow{3}{*}{05} & \multirow{3}{*}{ Annual income } & $\begin{array}{l}\text { Income Group I (up to } \\
\text { Rs 100000) }\end{array}$ & 78 & 65.00 & \multirow{3}{*}{180000} & \multirow{3}{*}{80000} \\
\hline & & $\begin{array}{l}\text { Income Group II (Rs } \\
100000-R s 260000)\end{array}$ & 24 & 20.00 & & \\
\hline & & $\begin{array}{ll}\text { Income } & \text { Group } \\
\text { (Above Rs } & \text { 260000) }\end{array}$ & 18 & 15.00 & & \\
\hline \multirow[t]{3}{*}{06} & \multirow{3}{*}{$\begin{array}{l}\text { Farming } \\
\text { Experience }\end{array}$} & Upto 11 Years & 81 & 67.50 & \multirow[b]{3}{*}{19.2} & \multirow[b]{3}{*}{7.94} \\
\hline & & 12-27 Years & 21 & 17.50 & & \\
\hline & & Above 27 Years & 18 & 15.00 & & \\
\hline \multirow[t]{3}{*}{07} & \multirow{3}{*}{$\begin{array}{l}\text { Source of } \\
\text { Information }\end{array}$} & Low( Upto Score 10) & 52 & 43.33 & \multirow{3}{*}{12.84} & \multirow{3}{*}{3.25} \\
\hline & & $\begin{array}{l}\text { Medium (Score } 11- \\
\text { Score 16) }\end{array}$ & 44 & 36.67 & & \\
\hline & & $\operatorname{High}(>$ Score 16$)$ & 24 & 20.00 & & \\
\hline \multirow[t]{3}{*}{08} & \multirow{3}{*}{$\begin{array}{l}\text { Economic } \\
\text { Motivation }\end{array}$} & Low ( Upto Score20) & 46 & 38.33 & & \\
\hline & & $\begin{array}{l}\text { Medium (Score 21- } \\
\text { Score 24) }\end{array}$ & 57 & 47.50 & 22.5 & 3.25 \\
\hline & & $\operatorname{High}(>$ Score 24) & 17 & 14.17 & & \\
\hline 09 & Risk Proneness & Low(Upto Score 14) & 47 & 39.17 & & \\
\hline & & $\begin{array}{l}\text { Medium(Score } \\
\text { Score 18) }\end{array}$ & 42 & 35.00 & 15.69 & 1.72 \\
\hline & & $\operatorname{High}(>$ Score 18) & 31 & 25.83 & & \\
\hline 10 & Scientific & Low (upto Score 26) & 68 & 56.67 & & \\
\hline & Orientation & $\begin{array}{l}\text { Medium } \\
\text { Score } 30)\end{array}$ & 35 & 29.17 & 27.56 & 1.17 \\
\hline & & High ( > Score 30) & 17 & 14.16 & & \\
\hline
\end{tabular}

$\mathrm{F}=$ Frequency, S.D=Standard Deviation 
Table.2 Association between Age of cherry growers with training needs

\begin{tabular}{|c|c|c|c|c|c|}
\hline \multirow[b]{2}{*}{ S.NO } & \multirow[b]{2}{*}{ Category } & \multicolumn{3}{|c|}{ Training needs } & \multirow[b]{2}{*}{ Total } \\
\hline & & Low & Medium & High & \\
\hline 01 & $\begin{array}{c}\text { Young } \\
\text { (Up to 36 years) }\end{array}$ & $\begin{array}{l}11 \\
(16.92)\end{array}$ & $\begin{array}{l}28 \\
(43.08)\end{array}$ & $\begin{array}{l}26 \\
(40.00)\end{array}$ & 65 \\
\hline 02 & $\begin{array}{l}\text { Middle age } \\
\text { (37-63 years) }\end{array}$ & $\begin{array}{l}8 \\
(21.05)\end{array}$ & $\begin{array}{l}6 \\
(15.79)\end{array}$ & $\begin{array}{l}24 \\
(63.16)\end{array}$ & 38 \\
\hline $\mathbf{0 3}$ & $\begin{array}{c}\text { Old age } \\
\text { (Above 63 years) }\end{array}$ & $\begin{array}{l}6 \\
(35.30)\end{array}$ & $\begin{array}{l}5 \\
(29.41)\end{array}$ & $\begin{array}{l}6 \\
(35.29)\end{array}$ & 17 \\
\hline & Total & 25 & 39 & 56 & 120 \\
\hline
\end{tabular}

$x^{2}=11.04$, significant at $5 \%$ level with 4 d.f.

Table.3 Association between Education level of cherry growers with training needs

\begin{tabular}{|c|c|c|c|c|c|}
\hline \multirow[b]{2}{*}{ S.NO } & \multirow[b]{2}{*}{ Education level } & \multicolumn{3}{|c|}{ Training needs } & \multirow[b]{2}{*}{ Total } \\
\hline & & Low & Medium & High & \\
\hline 01 & $\begin{array}{cc}\text { Low } & \text { (upto } \\
\text { middle standard) }\end{array}$ & $\begin{array}{l}9 \\
(13.84)\end{array}$ & $\begin{array}{l}25 \\
(38.46)\end{array}$ & $\begin{array}{l}31 \\
(47.70)\end{array}$ & 65 \\
\hline 02 & $\begin{array}{l}\text { Medium } \\
\text { (middle-10+2) }\end{array}$ & $\begin{array}{l}5 \\
(15.62)\end{array}$ & $\begin{array}{l}7 \\
(21.87)\end{array}$ & $\begin{array}{l}20 \\
(62.50)\end{array}$ & 32 \\
\hline 03 & $\begin{array}{c}\text { High } \\
\text { ( Above 10+2 ) }\end{array}$ & $\begin{array}{l}11 \\
(47.83)\end{array}$ & $\begin{array}{l}7 \\
(30.43)\end{array}$ & $\begin{array}{l}5 \\
(21.74)\end{array}$ & 23 \\
\hline Total & & 25 & 39 & 56 & 120 \\
\hline
\end{tabular}

$x^{2}=16.32$, significant at $5 \%$ level with 4 d.f.

Table.4 Association between Family size of the cherry growers with training needs

\begin{tabular}{|l|l|l|l|l|l|}
\hline \multirow{2}{*}{ S.NO } & Family size & \multicolumn{3}{|c|}{ Training needs } & \multirow{2}{*}{ Total } \\
\hline & Small (Upto & Low & Medium & High & \\
\hline $\mathbf{0 1}$ & members) & 6 & 7 & 10 & \\
$\mathbf{0 2}$ & Medium & $(26.08)$ & $(30.44)$ & $(43.48)$ & 23 \\
\hline $\mathbf{0 3}$ & (5-10members) & 11 & 19 & 35 & \\
\hline Total & Large & $(16.92)$ & $(29.23)$ & $(53.85)$ & 65 \\
\hline & (Above10 members) & 8 & 13 & 11 & \\
\hline
\end{tabular}

$x^{2}=3.74$, non-significant at $5 \%$ level with 4 d.f.

Table.5 Association between land holding of the cherry growers with training needs

\begin{tabular}{|c|c|c|c|c|c|}
\hline \multirow[b]{2}{*}{ S.NO } & \multirow[b]{2}{*}{ Land holding } & \multicolumn{3}{|c|}{ Training needs } & \multirow[b]{2}{*}{ Total } \\
\hline & & Low & Medium & High & \\
\hline 01 & $\begin{array}{l}\text { Marginal } \\
\text { (upto } 1 \text { hec) }\end{array}$ & $\begin{array}{l}15 \\
(17.04)\end{array}$ & $\begin{array}{l}\mathbf{3 0} \\
(34.09)\end{array}$ & $\begin{array}{l}43 \\
(48.86)\end{array}$ & 88 \\
\hline 02 & $\begin{array}{l}\text { Small } \\
(1,01-2 \text { hec })\end{array}$ & $\begin{array}{l}9 \\
(37.50)\end{array}$ & $\begin{array}{l}7 \\
(29.17)\end{array}$ & $\begin{array}{l}8 \\
(33.33)\end{array}$ & 24 \\
\hline 03 & $\begin{array}{l}\text { Medium } \\
(2.01-5 \text { hec })\end{array}$ & $\begin{array}{l}1 \\
(12.50)\end{array}$ & $\begin{array}{l}2 \\
(25.00)\end{array}$ & $\begin{array}{l}5 \\
(4.16)\end{array}$ & 8 \\
\hline Total & & 25 & 39 & 56 & 120 \\
\hline
\end{tabular}

$x^{2}=5.79 .04$, non-significant at $5 \%$ level with 4 d.f. 
Table.6 Association between Annual income of cherry growers with training needs

\begin{tabular}{|c|c|c|c|c|c|}
\hline \multirow[b]{2}{*}{ S.NO } & \multirow[b]{2}{*}{ Annual income } & \multicolumn{3}{|c|}{ Training needs } & \multirow[b]{2}{*}{ Total } \\
\hline & & Low & Medium & High & \\
\hline 01 & $\begin{array}{c}\text { Income group I (upto } \\
\text { Rs 100000) }\end{array}$ & $\begin{array}{l}11 \\
(14.10)\end{array}$ & $\begin{array}{l}27 \\
(34.62)\end{array}$ & $\begin{array}{l}40 \\
(51.28)\end{array}$ & 78 \\
\hline 02 & $\begin{array}{c}\text { Income } \\
(\text { Rs100000-Rs 240000) }\end{array}$ & $\begin{array}{l}8 \\
(33.33)\end{array}$ & $\begin{array}{l}6 \\
(25.00)\end{array}$ & $\begin{array}{l}10 \\
(41.67)\end{array}$ & 24 \\
\hline 03 & $\begin{array}{cc}\text { Income } & \text { group } \\
(\text { Above Rs } 240000) & \text { III }\end{array}$ & $\begin{array}{l}6 \\
(33.33)\end{array}$ & $\begin{array}{l}6 \\
(33.33)\end{array}$ & $\begin{array}{l}6 \\
(33.33)\end{array}$ & 18 \\
\hline Total & & 25 & 39 & 56 & 120 \\
\hline
\end{tabular}

$x^{2}=6.54$, non-significant at $5 \%$ level with 4 d.f.

Table.7 Association between Farming experience of cherry growers with training needs

\begin{tabular}{|c|c|c|c|c|c|}
\hline \multirow[b]{2}{*}{ S.NO } & \multirow[b]{2}{*}{ Farming experience } & \multicolumn{3}{|c|}{ Training needs } & \multirow[b]{2}{*}{ Tota } \\
\hline & & Low & Medium & High & \\
\hline 01 & $\begin{array}{c}\text { Low } \\
\text { (upto } 11 \text { years) }\end{array}$ & $\begin{array}{l}10 \\
(12.34)\end{array}$ & $\begin{array}{l}27 \\
(33.33)\end{array}$ & $\begin{array}{l}44 \\
(54.32)\end{array}$ & 81 \\
\hline 02 & $\begin{array}{l}\text { Medium } \\
\text { (12-27 years) }\end{array}$ & $\begin{array}{l}9 \\
(42.84)\end{array}$ & $\begin{array}{l}6 \\
(28.58)\end{array}$ & $\begin{array}{l}6 \\
(28.58)\end{array}$ & 21 \\
\hline 03 & $\begin{array}{l}\text { High } \\
\text { (Above } 27 \text { years ) }\end{array}$ & $\begin{array}{l}6 \\
(33.33)\end{array}$ & $\begin{array}{l}6 \\
(33.33)\end{array}$ & $\begin{array}{l}6 \\
(33.33)\end{array}$ & 18 \\
\hline Total & & 25 & 39 & 56 & 120 \\
\hline
\end{tabular}

$x^{2}=12.33$, significant at $5 \%$ level with 4 d.f.

Table.8 Association between Source of information of cherry growers with training needs

\begin{tabular}{|c|c|c|c|c|c|}
\hline \multirow[b]{2}{*}{ S.NO } & \multirow{2}{*}{$\begin{array}{cc}\text { Source } & \text { of } \\
\text { information }\end{array}$} & \multicolumn{3}{|c|}{ Training needs } & \multirow[b]{2}{*}{ Total } \\
\hline & & Low & Medium & High & \\
\hline 01 & $\begin{array}{c}\text { Low } \\
\text { ( upto score 10) }\end{array}$ & $\begin{array}{l}7 \\
(13.46)\end{array}$ & $\begin{array}{l}22 \\
(42.31)\end{array}$ & $\begin{array}{l}23 \\
(44.23)\end{array}$ & 52 \\
\hline 02 & $\begin{array}{l}\text { Medium } \\
\text { (score11- score 16) }\end{array}$ & $\begin{array}{l}8 \\
(18.18)\end{array}$ & $\begin{array}{l}12 \\
(27.27)\end{array}$ & $\begin{array}{l}24 \\
(54.55)\end{array}$ & 44 \\
\hline 03 & $\begin{array}{l}\text { High } \\
\text { ( Above score 16 ) }\end{array}$ & $\begin{array}{l}10 \\
(41.67)\end{array}$ & $\begin{array}{l}5 \\
(20.83)\end{array}$ & $\begin{array}{l}9 \\
(37.50)\end{array}$ & 24 \\
\hline Total & & 25 & 39 & 56 & 120 \\
\hline
\end{tabular}

$x^{2}=10.50$, significant at $5 \%$ level with 4 d.f.

Table.9 Association between economic motivation of cherry growers with training needs

\begin{tabular}{|c|c|c|c|c|c|}
\hline \multirow[b]{2}{*}{ S.NO } & \multirow[t]{2}{*}{ Economic motivation } & \multicolumn{3}{|c|}{ Training needs } & \multirow[b]{2}{*}{ Total } \\
\hline & & Low & Medium & High & \\
\hline 01 & $\begin{array}{l}\text { Low } \\
\text { (upto score 21) }\end{array}$ & $\begin{array}{l}5 \\
(10.87)\end{array}$ & $\begin{array}{l}22 \\
(47.82)\end{array}$ & $\begin{array}{l}19 \\
(41.30)\end{array}$ & 46 \\
\hline 02 & $\begin{array}{l}\text { Medium } \\
\text { (score 22- score 24) }\end{array}$ & $\begin{array}{l}14 \\
(24.56)\end{array}$ & $\begin{array}{l}11 \\
(19.30)\end{array}$ & $\begin{array}{l}32 \\
(56.14)\end{array}$ & 57 \\
\hline 03 & $\begin{array}{l}\text { High } \\
\text { ( Above score } 24 \text { ) }\end{array}$ & $\begin{array}{l}6 \\
(35.29)\end{array}$ & $\begin{array}{l}6 \\
(35.29)\end{array}$ & $\begin{array}{l}5 \\
(29.42)\end{array}$ & 17 \\
\hline Total & & 25 & 39 & 56 & 120 \\
\hline
\end{tabular}

$x^{2}=13.16$, significant at $5 \%$ level with 4 d.f. 
Table.10 Association between Risk proneness of cherry growers with training needs

\begin{tabular}{|c|c|c|c|c|c|}
\hline \multirow[b]{2}{*}{ S.NO } & \multirow[b]{2}{*}{ Risk proneness } & \multicolumn{3}{|c|}{ Training needs } & \multirow[b]{2}{*}{ Total } \\
\hline & & Low & Medium & High & \\
\hline 01 & $\begin{array}{l}\text { Low } \\
\text { (upto score 14) }\end{array}$ & $\begin{array}{l}11 \\
(23.40)\end{array}$ & $\begin{array}{l}15 \\
(31.91)\end{array}$ & $\begin{array}{l}21 \\
(44.69)\end{array}$ & 47 \\
\hline 02 & $\begin{array}{l}\text { Medium } \\
\text { (score 15- score } \\
\text { 17) }\end{array}$ & $\begin{array}{l}6 \\
(14.28)\end{array}$ & $\begin{array}{l}13 \\
(31.00)\end{array}$ & $\begin{array}{l}23 \\
(54.72)\end{array}$ & 42 \\
\hline 03 & $\begin{array}{l}\text { High } \\
\text { (Above score 17) }\end{array}$ & $\begin{array}{l}8 \\
(25.00)\end{array}$ & $\begin{array}{l}11 \\
(35.30)\end{array}$ & $\begin{array}{l}12 \\
(38.70)\end{array}$ & 31 \\
\hline Total & & 25 & 39 & 56 & 120 \\
\hline
\end{tabular}

$x^{2}=2.55$, significant at $5 \%$ level with 4 d.f.

Table.11 Association between Scientific orientations of cherry growers with training needs

\begin{tabular}{|c|c|c|c|c|c|}
\hline \multirow[b]{2}{*}{ S.NO } & \multirow[b]{2}{*}{$\begin{array}{l}\text { Scientific } \\
\text { orientation }\end{array}$} & \multicolumn{3}{|c|}{ Training needs } & \multirow[b]{2}{*}{ Total } \\
\hline & & Low & Medium & High & \\
\hline 01 & $\begin{array}{c}\text { Low } \\
\text { (upto score 26) }\end{array}$ & $\begin{array}{l}14 \\
(20.59)\end{array}$ & $\begin{array}{l}15 \\
(22.05)\end{array}$ & $\begin{array}{l}39 \\
(57.36)\end{array}$ & 68 \\
\hline 02 & $\begin{array}{l}\text { Medium } \\
\text { (score 27- score } \\
\text { 29) }\end{array}$ & $\begin{array}{l}5 \\
(14.29)\end{array}$ & $\begin{array}{l}18 \\
(51.42)\end{array}$ & $\begin{array}{l}12 \\
(34.29)\end{array}$ & 35 \\
\hline 03 & $\begin{array}{c}\text { High } \\
\text { (Above score 29) }\end{array}$ & $\begin{array}{l}6 \\
(35.29)\end{array}$ & $\begin{array}{l}6 \\
(35.29)\end{array}$ & $\begin{array}{l}5 \\
(29.42)\end{array}$ & 17 \\
\hline Total & & 25 & 39 & 56 & 120 \\
\hline
\end{tabular}

$x^{2}=12.05$, significant at $5 \%$ level with 4 d.f.

Table 9 clearly shows, that among cherry growers having low economic motivation, 47.82 per cent had medium training needs, 41.30 per cent and 10.87 per cent had high and low training needs respectively. Similarly, in case of cherry growers having medium economic motivation, 56.14 per cent had high training needs, 24.56 per cent and 19.30 per cent had medium and low training needs respectively. While in case of cherry growers having high economic motivation, 35.29 per cent each had low and medium training needs, followed by 29.42 per cent having high training needs respectively. The chi $^{2}$ value 13.16 was found to be significant at 5 per cent level of probability. Thus, the null hypothesis was rejected and it is concluded that economic motivation has an association with training needs of cherry growers.
From Table 10, it is clear from the data that cherry growers having low risk proneness, 44.69 per cent had high training needs, 31.91 per cent and 23.40 per cent had medium and low training needs respectively. Similarly, in medium risk proneness group, 54.72 per cent had high training needs, 31.00 per cent and 14.28 per cent had medium and low training needs respectively.

While in case cherry growers having high risk proneness , 38.70 per cent had high training needs, 35.30 per cent and 25.00 per cent had medium and low training needs respectively. The $\mathrm{chi}^{2}$ value 2.55 was found to be nonsignificant at 5 per cent level of probability. Thus, the null hypothesis was accepted and it can be concluded that the risk proneness had no association with the training needs of cherry growers. 
From Table 11, it was observed that cherry growers having low scientific orientation, 57.36 per cent had high training needs, 22.06 per cent and 20.59 per cent had medium and low training needs respectively. Similarly, in the case of respondents with medium scientific orientation, 51.43 per cent had medium training needs, 34.29 per cent and 14.29 per cent were having low and high training needs respectively. While in the case of respondents having high scientific orientation, 35.29 per cent had low, 35.29 per cent had medium and 29.42 per cent respondents had high training needs.

The $\mathrm{chi}^{2}$ value 12.05 was found to be significant at 5 per cent level of probability. Thus, the null hypothesis was rejected and it can be concluded that scientific orientation was associated with training needs of the cherry growers.

Thus it can be concluded that Age, Education, Farming Experience, Source of information, Economic motivation and Scientific orientation had significant association with training needs. The work of Dixit and singh (2005) and Aske (2008) supports the findings of present study. Whereas, Family size, land holding, annual income and risk proneness had non-significant association with the training needs of the cherry growers. The work of Patel (2007) and Ghodeswar (2006) are in line with present findings.

More than half of the cherry growers $(54.16 \%)$ belonged to young age group. About 57.17\% cherry growers were educated up to middle school. Majority of cherry growers $(54.17 \%)$ had medium family size(5-10 members). Majority of the cherry growers $(73.33 \%)$ had marginal land holding. Maximum number of cherry growers $(65 \%)$ belonged to low income category. Majority of cherry growers $(67.50 \%)$ had low level of experience in cherry cultivation.

Majority $(43.33 \%)$ of the cherry growers had medium level of source of information. Majority of the cherry growers $(47.50 \%)$ had edium level of economic motivation. Majority of the cherry growers $(39.17 \%)$ possessed low level of risk proneness. Majority of the cherry growers $(56.66 \%)$ possessed low level of scientific orientation.

The study revealed that Age, Education, Farming Experience, Source of information, Economic motivation and Scientific orientation had significant association with training needs.

\section{References}

Ali, A., Sharief, M. and Mahmood, K. (2013): Determinants of Cherry Production and Marketing in Pakistan: A Propensity Score Matching Approach14(1): 57-63.

Anonymous, (2012): Cherry production: United Nations: Statistical Database Agriculture; Food and Agricultural organization (FAO).

Anonymous, (2015): Major cherry producing countries in the world; Directorate of Economics and Statistics: Department of Agricultural and cooperation, FAO.

Anonymous, (2017): Area and production of horticulture crops in Jammu and Kashmir: Economic survey of horticulture crops in Jammu and Kashmir; District Baramulla. Government of Jammu and Kashmir.

Asane, P. G. (2003): Knowledge and adoption of cultivation practices recommended for chickpea. Unpublished Thesis abstracts, Department of Extension Education, CSKHPKV, Palampur, (H.P) India.

Chadha, K. L. (2003): Characteristics of cherry: Handbook of horticulture. Delhi, India; Directorate of information and publications of Agriculture, Indian council of Agriculture Research (ICAR): 7-13.

Chowdhary, R. K. S. (2006): A study an entrepreneurial behaviour of potato growers in Malwa region of Madhya Pradesh; M.Sc. Agriculture Thesis (unpublished) J.N.K.V.V Jabalpur, India.

Dolli, S. S. and Sundaraswamy, B. (1994): Influence of socio-economic factors on technological gap in the cultivation of pulses crop: Maharashtra Journal of Extension Education, 13(1): 80-83.

Ghodeswar, N. A. (2006): Knowledge and 
adoption of recommended pre and postharvest technology in pomegranate cultivation: M.Sc. Agriculture Thesis (unpublished) VNMKV Parbhani, (M.S.) India.

Halim, A. and Ali, M. M. (1988): Administration and management of training programme; Bangladesh Journal of Training and Devlopment 1(2): 1-19.

Hanumanlal and Pawar (1995): A study on Training needs and constraints of the pomegranate cultivators of Solapur district; (MH): Agriculture Update 4(3\&4):282284.

Hipperkar, B. G. (2015): Entrepreneurial behaviour of pomegranate growers in Aurangabad district; M.Sc. Agriculture. (Unpublished) Thesis VNMKV, Parbhani. Maharashtra, India.

Kadam, R. P., Umate, S. M., Pawar, G. S. and Waghmare, O. R. (2014): Assessment of training needs of sweet orange growers in Marathwada region: Agriculture Update 9(3): 354-359.

Khandare, K. A. (2003): A study on training needs of grape grower about plant protection measures; M.Sc. Agriculture Thesis, (unpublished), VNMKV, Parbhani. (M.S.), India.

Laxminarayana, M.T., Anand, T.N., Manjunath, B.N. and Rannganath, A.P. (2000). Impact of training needs on knowledge level of farm youths. National Seminar on Extnension Education System. Abstract, organized by Konkan Vidyapeeth, Dapoli, Akola, Maharashtra Society of Extension Education, 18(2) 65-68.

Patel, A.K. (2007): A study on analysis of training needs of Gram growers for plant protection measures in Naighadi block of Rewa district (M.P.). M.Sc. Agriculture Thesis (unpublished), JNKVV, Jabalpur, India.

Patel, S. R.. (2006): A study on managerial efficiency of aonla growers of Anand and
Kheda districts of Gujarat state; Ph.D. Agriculture thesis unpublished, AAU, Anand Gujarat, India.

Patalia, N. R. (1991): A study on the extent of adoption and recommended mango cultivation by the growers in parbhani district; M.SC. Agriculture thesis (unpublished) submitted to Marathwada Agriculture University, Parbhani (M.S), India.

Prajapati, I.B. (2006). A study on socio-economic factors responsible for technological gap of recommended wheat technology among tribal farmers of Sidhi block of Sidhi district (M.P.). M.Sc. Agriculture Thesis (unpublished), JNKVV, Jabalpur, India.

Raghuwanshi, R. (2014): A study on training needs of potato growers in Gwalior District (M.P.); M.Sc Agriculture thesis (unpublished) submitted to R.V.S.K.V.V, Gwalior (M.P) India.

Singh, S., Khaddar., V. K., Ahirwar, R.. P. and Leelavati. (2012): Crop productivity and training needs of beneficiary farmers in watershed development programme; Indian Research Journal of Extension Education 1(1):303-306.

Shah, Z., Singh, R., Dar, M .A., Jehangir, M. M., and Mir, R. (2017): An Analysis of Sociopersonal Characteristics of Apple Growers and Their Attitude towards Apple Cultivation in District Shopian of J\&K ; Advances in Research India. 12(1): 1-11, 2017.

Lokhande, R.K. (2007): A study on adoption of integrated pest management practices by chickpea growers in Indore district of M.P; M.Sc. Agriculture Thesis, (unpublished), JNKVV, Jabalpur, India.

Waghmare, O. R. (2010): Training needs of sweet orange growers: M.Sc. Agriculture Thesis, (unpublished), VNMKV Parbhani (M.S.) India

\section{How to cite this article:}

Dawood Yousuf, M. A. Dar, Noor Ul Islam Wani, Nakeeb Raja, Junaid Rishu and Aamir Hamid Shah. 2020. Association of Socio-Economic Characteristics with the Training Needs of Cherry Growers- A Study in Baramulla District of Kashmir Valley. Int.J.Curr.Microbiol.App.Sci. 9(05): 2547-2559. doi: https://doi.org/10.20546/ijcmas.2020.905.291 